\title{
Regional Coverage with Banking Services and Regional Economic Health
}

\author{
O.G. Lebedinskaya ${ }^{1, *}, A . G$. Timofeev ${ }^{1}$ and $M . V$. Kurnikova $^{2}$ \\ * Corresponding author:lebedinskaya19@gmail.com \\ ${ }^{1}$ Plekhanov Russian University of Economics, Moscow, Russia \\ ${ }^{2}$ Samara State University of Economics, Samara, Russia
}

\begin{abstract}
Economic developments are rapidly accelerating, and the world is becoming even more complicated. Recently, the world has witnessed the trend toward the reduction of household contribution and growing contribution of non-financial corporations as well as the one of public administration to GDP within its institutional structure. The main problem in Russia results from huge territories and low interest of investors due to weak guarantees of investment protection. The banks with large state-owned shareholding do not always match their activities with the interests of the State. Low penetration of banking services into regions results from their low capitalization, low level of financial literacy, insufficient demand for banking services from the population and unfair competition posed by state-owned banks. With the general problems of banking sector added by regional factors, the derived statistics is extremely controversial. The solution of this problem needs durable solutions.
\end{abstract}

Keywords: Banking services, region, estimation, saturation efficiency, availability index, loans.

\section{Introduction}

Russian banking services market is traditionally complicatedly differentiated across regions. According to the methodology of The Bank of Russia, the imbalance of banking services coverage is mostly in favor of central regions, while peripheral regions in terms of development, are lagging behind, however, that is not always true. The adjusted banking services coverage of Russian regions across regions and federal districts enabled to shed new light on the established distribution.

\section{Problem Statement}

The methodology for assessing regional socio-economic potential is able to determine its further development and characterize the degree of regional readiness to adsorb and continue innovations based on an integrative indicator 'economic health index'. The lack of existing approaches to assessing the socio - economic situation of the regions is that it is not always possible to correctly identify the cause-and-effect relations and to determine the trends in the development of the subject

\section{Research Questions}

The research is focused on the following issues:

3.1. The study of key concepts estimating regional development of banking services;

3.2. The identification of regional banking market specifics based on the given procedure.

\section{Purpose of the Study}

The purpose of the study is to assess the dynamics of the regional development of the banking market and the economic health of the region as a whole. Grouping of regions on the basis of assigned ratings will allow making a more accurate forecast of their development and, as a result, to develop a correct strategy for further development.

\section{Research Methods}

The coverage level of Russian regions with banking services was analyzed and assessed with the use of the Bank of Russia procedure [1]. The procedure is based on the study of a set of indicators concerning institutional characteristics and banking sector infrastructure in a region, concentration of assets, loan activity in real economy, public demand for 
financial services. The authors used an integrated indicator - 'integrated coverage index of a region with banking services' as a result indicator [2].

\section{Findings}

The authors agree with an idea [3] on the necessity to adjust the approach toward increasing the number of indicators being analyzed. The reason for such an adjustment is connected with its disadvantages: only population is taken into account to estimate institutional coverage while it should be replaced by regional GDP. Moreover, the accuracy of estimates is hampered by the use of credit organizations assets without estimating own means. Furthermore, loans to private individuals should preferably be estimated per head of population and not with GDP per head of population [4].

Thereafter, the aggregate index of regional coverage with banking services be calculated in accordance with the following formula (1):

$$
\mathrm{A} I_{B S}=\sqrt[8]{\mathrm{I}_{P} \times \mathrm{I}_{G D P} \times I_{\mathrm{A}} \times I_{\mathrm{C}} \times \mathrm{I}_{L(I)} \times \mathrm{I}_{L(B)} \times \mathrm{I}_{\mathrm{TI}} \times \mathrm{I}_{P S}}
$$

The aggregate index shows the composition and the procedure of estimating supporting indicators (2-9):

$I_{P}$ - is calculated as the ratio of the number of organizations in a region (including branches and sub-offices) to the population at the reporting date adjusted for the respective rate in Russia

$$
\mathrm{I}_{\mathrm{P}}=\frac{\mathrm{N}}{\mathrm{P} \times \mathrm{RRR}}
$$

$\mathrm{I}_{\mathrm{GDP}}$ - is calculated as the ratio of the number of organizations in a region (including branches and sub-offices) to GDP adjusted for the respective rate in Russia

$$
\mathrm{I}_{\mathrm{GDP}}=\frac{\mathrm{N}}{\mathrm{GDP} \times \mathrm{RRR}}
$$

$I_{A}$ - is calculated as the ratio of balances for assets to GDP adjusted for the respective rate in Russia

$$
\mathrm{I}_{\mathrm{A}}=\frac{\mathrm{A}}{\mathrm{GDP} \times \mathrm{RRR}}
$$

$\mathrm{I}_{\mathrm{C}}$ - is calculated as the ratio of own assets (capital) to GDP adjusted for the respective rate in Russia

$$
\mathrm{I}_{\mathrm{C}}=\frac{\mathrm{C}}{\mathrm{GDP} \times \mathrm{RRR}}
$$

$\mathrm{I}_{\mathrm{L}(\mathrm{I})}$ - is calculated as the ratio of loans issued to individuals to GDP adjusted for the respective rate in Russia

$$
\mathrm{I}_{\mathrm{L}(\mathrm{I})}=\frac{\mathrm{L}(\mathrm{I})}{\mathrm{GDP} \times \mathrm{RRR}}
$$

$I_{L(B)}$ - is calculated as the ratio of loans issued to businesses to GDP adjusted for the respective rate in Russia

$$
\mathrm{I}_{\mathrm{L}(\mathrm{B})}=\frac{\mathrm{L}(\mathrm{B})}{\mathrm{GDP} \times \mathrm{RRR}}
$$

$\mathrm{I}_{\mathrm{TI}}$ - shows individuals deposits coverage as a proportion of aggregate personal income

$$
\mathrm{I}_{\mathrm{TI}}=\frac{\mathrm{D}(\mathrm{I})}{\mathrm{P} \times \mathrm{API} \times \mathrm{RRR}}
$$

$I_{P S}$ - is calculated as the ratio of paid services to GDP adjusted for the respective rate in Russia

$$
\mathrm{I}_{\mathrm{PS}}=\frac{\mathrm{N}_{\mathrm{PS}}}{\mathrm{GDP} \times \mathrm{RRR}}
$$

The analysis revealed substantial regional differentiation in market services coverage despite the best efforts of the Central Bank which is flattened by the statistics of federal districts. The maximum values of the Index were observed in only three Russian subjects: the Kostroma Region, St Petersburg and Moscow. Another four subjects formed a group of catching-up - the Karachayevo-Cherkessian Republic and the Republic of Tatarstan, the Chukotka Autonomous District and the Amur Region (see Table 1). 
Table 1. Grouping of Russian subjects according to index of regional coverage with banking services

\begin{tabular}{|c|c|c|c|c|c|}
\hline No & Index values & \multicolumn{2}{|c|}{$\mathbf{2 0 1 6}$} & \multicolumn{2}{|c|}{2017} \\
\cline { 3 - 6 } & & $\begin{array}{c}\text { Number of } \\
\text { Russian } \\
\text { subjects in the } \\
\text { group }\end{array}$ & $\begin{array}{c}\text { Average } \\
\text { index values } \\
\text { in the group }\end{array}$ & $\begin{array}{c}\text { Number of } \\
\text { Russian } \\
\text { subjects in the } \\
\text { group }\end{array}$ & $\begin{array}{c}\text { Average } \\
\text { index values } \\
\text { in the group }\end{array}$ \\
\hline $1^{\text {st }}$ group & up to 0,4336 & 54 & 0,2955 & 54 & 0,2971 \\
\hline $2^{\text {nd }}$ group & $0,4336-0,7240$ & 24 & 0,5545 & 23 & 0,5445 \\
\hline $3^{\text {rd }}$ group & $0,7240-1,0144$ & 4 & 0,8279 & 5 & 0,7776 \\
\hline $4^{\text {th }}$ group & $1,0144-1,3048$ & 1 & 1,3504 & & \\
\hline $5^{\text {th }}$ group & over 1,3048 & 2 & 1,8936 & 3 & 1,7884 \\
\hline
\end{tabular}

Source: compiled by the authors.

One should note that both subsidized region and the Moscow and Leningrad Regions - 'leader satellites' - belong to the regions with the lowest levels of banking services. The gap between outsiders and leaders is great and continues to increase: index maximum values for Moscow (2.1975 in 2016 and 2.2456 in 2017) are nearly 15 times as high as index minimum values for the Voronezh Region ( 0.1569 and 0.1691 comparatively). However, we should point out positive growth development of Index mode values from 0.2993 in 2016 to 0.3583 in 2017 (see Table 2).

Table 2. The specifications of variation series

\begin{tabular}{|c|c|c|c|c|c|c|c|c|}
\hline$\stackrel{\Xi}{\overparen{\sigma}}$ & $\frac{0}{\stackrel{0}{0}}$ & 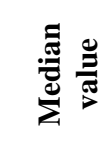 & 离 & 莺总 & 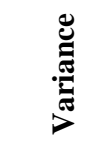 & 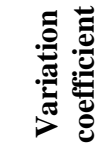 & 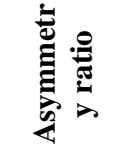 & 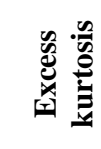 \\
\hline 2016 & 0.2993 & 0.3630 & 0.1798 & 0.5634 & 0.1093 & 0.7921 & 0.1644 & 8.7119 \\
\hline 2017 & 0.3583 & 0.3850 & 0.1948 & 0.5648 & 0.1053 & 0.7633 & 0.1236 & 9.3278 \\
\hline
\end{tabular}

Source: compiled by the authors.

Let us focus on the analysis results of indicators across certain federal districts.

The Far East federal district is leading with a slight breakaway according to the indicator 'Index of institutional coverage with banking services' (see Fig. 1)

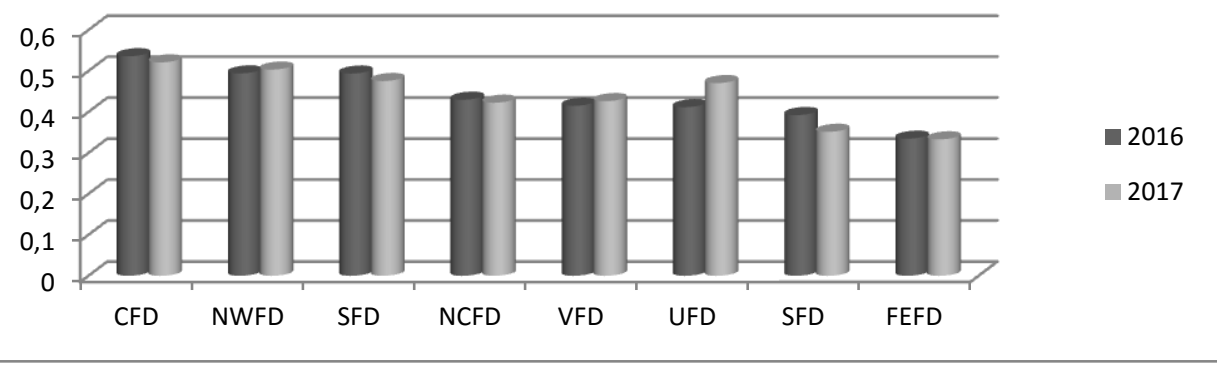

Figure 1. The distribution of federal districts according to the aggregate index of district coverage with banking services (Source: compiled by the authors)

The second and third positions are occupied by the Central federal district and the Northwest federal district with a small gap between them. High level of the CFO was provided by Moscow (2.1975). Otherwise, the index value for that region would hardly amount to 0.394 moving it to the second-last position. The same situation occurred in the Northwest federal district where St Peterburg has become an engine of growth (1.5951). Across Russian subjects, the best development of the index over the period under analysis was shown by the Kostroma Region $(+13.11$ per cent), the Pskov Region (+5.01 per cent), the Republic of Ingushetia ( +7.76 per cent), the Republic of Tatarstan $(+5.15$ per cent), the Yamalo-Nenets Autonomous District (+9.92 per cent), the Zabaykalsky Territory (+8.08 per cent) and the Khabarovsk Territory (+6.2per cent).

The analysis of median values according to the above-mentioned indicators revealed other facts. Thus, according to $I_{P}$, the first quartile involved representatives of only four federal districts, with their general number of 22 regions, with the Central Federal District having higher positions in the group (the Kabardino-Balkarian Republic, the Tchetchen Republic, the Kursk Region, the Kalmyk Republic, the Republic of Mordovia, the Republic of Khakassia), four representatives of both the Volga Federal District and the Northwestern federal district, the proportion of regions of the Siberian Federal District amounts to 33.3 per cent. Mode value of the indicator is 0.62 .

According to $I_{T I}$, mode value is 0.812 . The first quartile is formed by representatives of almost all federal districts. All the Far East Federal District, the Volga Federal District and the Northwestern Federal District are represented by one region each (the Tchetchen Rebublic - 0.164, the Republic of Ingushetia -0.124 and the Rebublic of Dagestan 0.148 respectively), the Ural Federal District is represented by four subjects, with largest number of regions representing the North Caucasian Federal District). 
The indicator 'Index of financial coverage with banking services (in terms of loans issued to individuals)' $I_{L(I)}$ showed maximum variety. The variation amounts to almost 200. Such differentiation may be connected with low population density. Thus, minimum values of the indicator were revealed in the Republic of Crimea (0.012) and the City of Sevastopol (0.014), Ingushetia (1.124), Dagestan (0.148), the Tchetchen Republic (0.164). Maximum values were registered in the Yamalo-Nenets (2.269) and Khanty-Mansi Autonomous Districts, the Magadan (1.889) and Tymen (1.715) Regions.

The indicator 'Index of financial coverage with banking services (in terms of loans issued to businesses)' $I_{L(B)}$ revealed slightly smaller variation of regions following the same logic. Low population density is added by the fact that most businesses have head offices in central Russia. Thus, maximum values were obtained by three regions of the Central Federal District: Moscow (1.232), the Moscow Region (1.355) and the Kursk region (1.204), and St Petersburg (1.204), the Vladimir Region (2.019) and the Republic of Mordovia (1.550).

Despite the fact that the Central Federal District occupies leading positions in four indices out of eight ('Index of financial coverage with banking services in terms of assets' (0.4499), 'Index of financial coverage with banking services (in terms of loans issued to businesses)' (0.9494), 'Index of financial coverage with banking services in terms of capital' (0.39800) and 'Thrift industry development index' (1.0726), the Far East Federal District is the leader in the aggregate index in 2017 (0.521) (see Table 3). The lowest indicators were obtained by the Siberian Federal District (0.3331).

Table 3. The distribution of federal districts according to the indicator 'Aggregate index of regional coverage with banking services'

\begin{tabular}{|c|c|c|c|c|c|c|c|c|c|}
\hline \multirow[t]{2}{*}{ Index } & \multirow[t]{2}{*}{ Period } & \multicolumn{8}{|c|}{ Federal Districts } \\
\hline & & CFD & NWFD & SFD & NCFD & VFD & UFD & SFD & FEFD \\
\hline \multirow[t]{2}{*}{$I_{P}$} & 2016 & 0.8031 & 2.3645 & 0.6125 & 0.6833 & 0.5129 & 0.8339 & 0.5591 & 2.2931 \\
\hline & 2017 & 0.8341 & 2.6628 & 0.7152 & 0.6955 & 0.5328 & 1.0199 & 0.5619 & 2.1607 \\
\hline \multirow[t]{2}{*}{$I_{G D P}$} & 2016 & 0.9002 & 0.8054 & 1.3974 & 1.9391 & 0.7701 & 0.4860 & 0.9845 & 1.2721 \\
\hline & 2017 & 0.9766 & 0.8441 & 0.8515 & 2.0891 & 0.7992 & 0.5398 & 0.9761 & 1.3929 \\
\hline \multirow[t]{2}{*}{$I_{A}$} & 2016 & 0.3916 & 0.3997 & 0.1225 & 0.1302 & 0.0996 & 0.1160 & 0.0319 & 0.1919 \\
\hline & 2017 & 0.4499 & 0.4071 & 0.1715 & 0.1123 & 0.0863 & 0.1099 & 0.0318 & 0.1657 \\
\hline \multirow[t]{2}{*}{$I_{C}$} & 2016 & 0.3540 & 0.3574 & 0.1115 & 0.0987 & 0.1023 & 0.1050 & 0.0402 & 0.2277 \\
\hline & 2017 & 0.3980 & 0.3307 & 0.1500 & 0.0913 & 0.0986 & 0.1070 & 0.0403 & 0.1966 \\
\hline \multirow[t]{2}{*}{$I_{L(I)}$} & 2016 & 0.9639 & 0.6897 & 0.5481 & 0.6446 & 0.8671 & 0.6262 & 0.6375 & 0.4467 \\
\hline & 2017 & 0.9494 & 0.6376 & 0.5686 & 0.6415 & 0.8250 & 0.7518 & 0.6232 & 0.4045 \\
\hline \multirow{2}{*}{$I_{L(B)}$} & 2016 & 0.8563 & 1.1511 & 0.6713 & 0.4350 & 0.8857 & 1.6056 & 1.0682 & 1.2818 \\
\hline & 2017 & 0.8608 & 1.1709 & 0.6741 & 0.4132 & 0.8898 & 1.6568 & 1.0442 & 1.2863 \\
\hline \multirow[t]{2}{*}{$I_{T I}$} & 2016 & 1.0726 & 1.1658 & 0.7087 & 0.5305 & 0.8999 & 0.7432 & 0.8076 & 1.0335 \\
\hline & 2017 & 1.0726 & 0.1394 & 0.6923 & 0.5404 & 0.9277 & 0.7268 & 0.8117 & 1.0357 \\
\hline \multirow[t]{2}{*}{$I_{P S}$} & 2016 & 1.1492 & 0.9861 & 1.8984 & 0.6258 & 1.1101 & 0.7891 & 0.9980 & 1.1239 \\
\hline & 2017 & 1.1112 & 0.9419 & 1.9417 & 1.6429 & 1.0928 & 1.7725 & 0.9914 & 0.1104 \\
\hline \multirow[t]{2}{*}{$\mathrm{A} I_{B S}$} & 2016 & 0.4942 & 0.4938 & 0.4118 & 0.3925 & 0.4299 & 0.4150 & 0.3348 & 0.5361 \\
\hline & 2017 & 0.5035 & 0.4755 & 0.4705 & 0.3515 & 0.4226 & 0.4265 & 0.3331 & 0.5210 \\
\hline
\end{tabular}

Source: compiled by the authors.

The model takes into account institutional parameters of interaction in economic space of market agents and the state as well as the factors having a qualitative and quantitative impact on institutional environment of banking services market development. The study showed that the development of banking services market should be based on the principle of serving interests of all institutional subjects.

Commercial banks use different approaches and criteria to choose regions of further development of their networks using such widely used criteria as the level and dynamics of population income, the number of population and businesses, in this, undermining the impact of other factors. The authors calculated Regional Economic Health Index in order to use it as such a marker (10).

$$
E H I_{R}=\sqrt[6]{I_{B} \times I_{F I} \times I_{T} \times I_{P S} \times \frac{1}{I_{U}} \times \frac{1}{I_{I n f}}}
$$

где $I_{B}$ - work on building growth index;

$I_{T}$ - retail trade turnover growth index;

$I_{F I}$ - fixed investment growth index;

$I_{P S}$ - paid services growth index;

$I_{U}$ - unemployment dynamics index;

$I_{\text {Inf }}$ - inflation dynamics index.

Table 4 shows the results of the calculation.

Table 4. The distribution of federal districts according to Regional Economic Health Index

\begin{tabular}{|c|c|c|c|c|c|c|c|c|c|}
\hline \multirow{2}{*}{ Index } & Period & \multicolumn{8}{|c|}{ Federal Districts } \\
\cline { 3 - 10 } & & CFD & NWFD & SFD & NCFD & VFD & UFD & SFD & FEFD \\
\hline \multirow{2}{*}{$I_{B}$} & 2016 & 0.7312 & 1.5180 & 0.5826 & 0.5203 & 0.8095 & 2.0177 & 0.7325 & 1.5837 \\
\cline { 2 - 10 } & 2017 & 0.7027 & 1.6065 & 0.5587 & 0.5160 & 0.7600 & 2.2097 & 0.7382 & 1.6561 \\
\hline
\end{tabular}




\begin{tabular}{|c|c|c|c|c|c|c|c|c|c|}
\hline \multirow{2}{*}{$\mathrm{I}_{\mathrm{I}}$} & 2016 & 7.6870 & 34.0689 & 6.6478 & 4.6033 & 7.7317 & 39.6363 & 6.8978 & 21.5184 \\
\cline { 2 - 10 } & 2017 & 7.5742 & 27.7849 & 5.9077 & 4.5282 & 7.0155 & 48.1505 & 6.4844 & 19.5134 \\
\hline \multirow{3}{*}{$\mathrm{I}_{\mathrm{T}}$} & 2016 & 0.9445 & 0.9333 & 0.7626 & 0.6655 & 0.7905 & 1.0719 & 0.7074 & 0.9644 \\
\cline { 2 - 10 } & 2017 & 0.9505 & 0.9417 & 0.7979 & 0.6616 & 0.7877 & 1.0248 & 0.7040 & 0.9880 \\
\hline \multirow{3}{*}{$\mathrm{I}_{\mathrm{PS}}$} & 2016 & 0.0186 & 0.0093 & 0.0136 & 0.0064 & 0.0121 & 0.0143 & 0.0080 & 0.0065 \\
\cline { 2 - 10 } & 2017 & 0.0192 & 0.0093 & 0.0136 & 0.0063 & 0.0118 & 0.0140 & 0.0078 & 0.0064 \\
\hline \multirow{3}{*}{$\mathrm{I}_{\mathrm{U}}$} & 2016 & 0.8343 & 1.1282 & 1.3795 & 2.5128 & 0.8673 & 1.0476 & 1.5655 & 1.0377 \\
\hline \multirow{3}{*}{$\mathrm{I}_{\text {inf }}$} & 2017 & 0.8626 & 1.1835 & 1.3318 & 2.5247 & 0.8974 & 1.0424 & 1.6439 & 1.0222 \\
\hline \multirow{2}{*}{$\mathrm{EHI}_{\mathrm{R}}$} & 2016 & 1.0012 & 1.0019 & 1.0221 & 1.0186 & 0.9894 & 1.0000 & 0.9895 & 0.9908 \\
\cline { 2 - 10 } & 2016 & 1.0012 & 0.9963 & 1.0025 & 0.9951 & 0.9918 & 1.0041 & 0.9943 & 1.0002 \\
\cline { 2 - 10 } & 2017 & 0.6281 & 0.6874 & 0.4939 & 0.3899 & 0.6213 & 0.8678 & 0.4933 & 0.6848 \\
\hline
\end{tabular}

Source: compiled by the authors.

According to the data shown in Table 4 the Ural Federal Districts (0.8846) has leading positions across federal districts, the group of 'sustainable leaders' is represented by the Far East, North Western and Central Federal Districts (see Fig. 2). Across regions, locomotives of development traditionally are Moscow (1.6584), St Petersburg (1.3404), the Krasnodar Territory (0.86), the Republic of Tatarstan (1.0555), the Khanty Mansi (1.1155) and the Yamal Nents Autonomous Areas (1.5973) and the Sakhalin Region (1.0541).

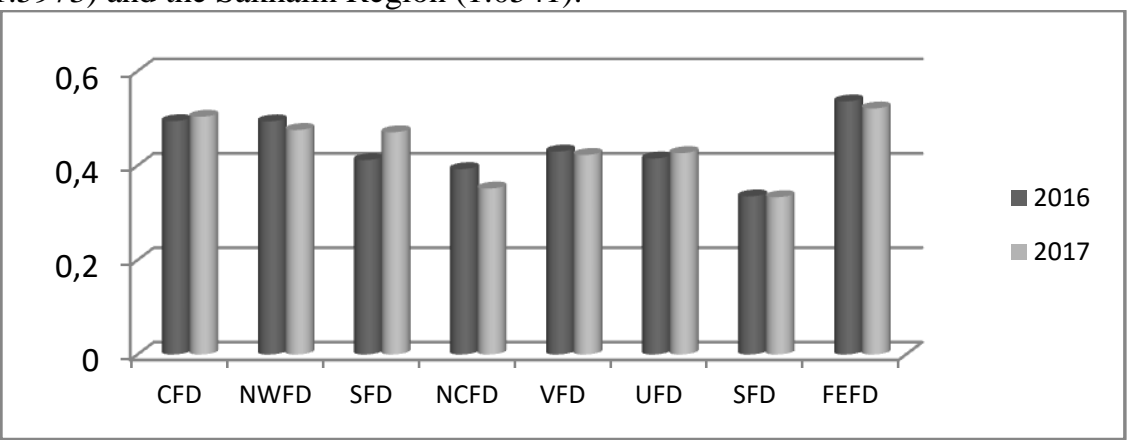

Figure 2. Regional Economic Health Index across federal districts (Source: compiled by the authors)

Top 10 of regions in all spheres is usually the same and depends on trade development level. One great advantage of calculating this index is that it matches main principals of conducting complex estimation of the level of socioeconomic development providing its comprehensiveness, systemacity and veracity.

\section{Conclusion}

The analysis of banking services coverage based on the adjusted model enabled to provide a more exact characteristics of regional development. The results obtained by the authors allow to state that the values of Regional Economic Health Index are directly or indirectly influenced by regional coverage with banking services $\left(R^{2}=0.89\right)$.

Domestic banking sector is historically shifted in favour of the metropolitan region. The second positions are occupied by St Petersburg, the Novosibirsk and the Rostov Districts, the Kamtchatka Territory. Most regions are much lower from the sufficient level. Insufficient coverage results from low bank capitalization and high regulatory barriers.

\section{References}

1. O. Dyachenko, N. Rodova, The estimation of regional coverage with banking services. Banking Review, 10, 23-43 (2013). [in Rus.].

2. V. Ghamsa, Main problems and development ways of Russian banking system. Analytical Banking Journal, 3-4 (2013). [in Rus.].

3. V.M. Zaernyuk, The analysis of methodical approaches to estimating the coverage of Russian regions with banking services. In A. Plotnikov, A. Petushkov and L. Tyagunov (Eds.) Proceedings of the International Scientific and Psractical Conference 'Actual Issues of Socio-Economic Development in Modernization', (pp. 123-127) Saratov (2011). [in Rus.].

4. F.I. Aminova, Improving the methodology for estimating regional coverage with banking services. Bulletin of Saint Petersburg State University of Economics, 8(75), 70-72 (2014). [in Rus.]. 